\title{
Adult Hope Scale
}

National Cancer Institute

\section{Source}

National Cancer Institute. Adult Hope Scale. NCI Thesaurus. Code C123340.

A 12-item measure of a respondent's level of hope. Each item is answered using an 8point Likert-type scale ranging from Definitely False to Definitely True. 